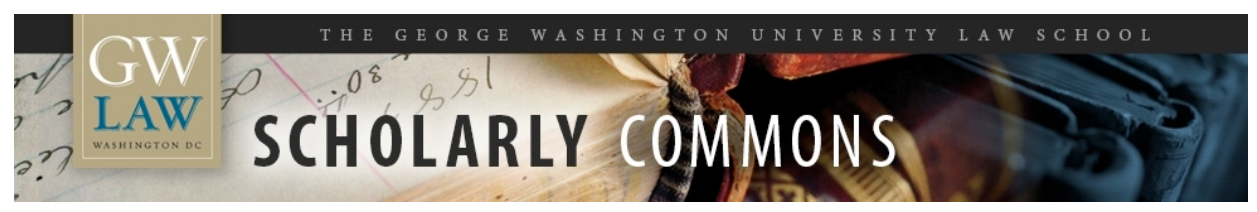

\title{
How WTO Dispute Settlement Succumbed to the Trump Administration
}

Steve Charnovitz

George Washington University Law School, scharnovitz@law.gwu.edu

Follow this and additional works at: https://scholarship.law.gwu.edu/faculty_publications

Part of the Law Commons

\section{Recommended Citation}

Charnovitz, Steve, How WTO Dispute Settlement Succumbed to the Trump Administration (December 17, 2019). GWU Law School Public Law Research Paper No. 2019-73; GWU Legal Studies Research Paper No. 2019-73. Available at SSRN: https://ssrn.com/abstract=3505266

This Article is brought to you for free and open access by the Faculty Scholarship at Scholarly Commons. It has been accepted for inclusion in GW Law Faculty Publications \& Other Works by an authorized administrator of Scholarly Commons. For more information, please contact spagel@law.gwu.edu. 


\title{
How WTO Dispute Settlement Succumbed to the Trump Administration
}

\author{
Steve Charnovitz ${ }^{1}$
}

The December 10 termination ${ }^{2}$ of the Appellate Body of the World Trade Organization (WTO) by the U.S. government is an unprecedented event in international economic law and US diplomatic history. The US government has refused to join some international courts that it had a major had in creating, such as the International Criminal Court and the Permanent Court of International Justice. But until now, the United States has never sought to and successfully destroyed an international tribunal from within. Thus, the shuttering of the Appellate Body has to be considered a major success of the Trump Administration's nihilistic approach to US participation in global economic governance. Without an Appellate Body to process appeals, a government losing a WTO panel decision can now appeal the ruling in order to prevent it from going into force.

Over the past 25 years, my scholarship has often discussed the Appellate Body- in particular, its institutional features, its jurisprudence, and its judges. ${ }^{3}$ Most of those writings were

\footnotetext{
${ }^{1}$ Prof. Charnovitz teaches at GWU Law School.

${ }^{2}$ As of 12 December 2019, the Appellate Body has one remaining judge who cannot undertake any official duties because a judicial quorum does not exist. The WTO has recently cut its budget for the Appellate Body so that the funding will dry up early in 2020. For some appeals now in Appellate chambers, there are rumors that those decisions will be handed down in the next several weeks. In my view, the legitimacy of those holdover benches is questionable.

${ }^{3}$ For example, among my writings, see "New WTO Adjudication and its Implications for the Environment," International Environment Reporter, 18 Sept. 1996; "The WTO's Alcoholic Beverages Decision," Review of European Community \& International Environmental Law, 1997; "The World Trade Organization, Meat Hormones, and Food Safety," International Trade Reporter, 15 Oct. 1997; "Environment and Health Under WTO Dispute Settlement," International Lawyer, Fall 1998; "World Trade Organization Turtle Decision Makes Progress," Journal of International Wildlife Law and Policy, 1998; "Improving the Agreement on Sanitary and Phytosanitary Standards," in Trade, Environment and the Millennium (United Nations University Press, 1999); "The Supervision of Health and Biosafety Regulation by World Trade Rules," Tulane Environmental Law Journal, Summer 2000; "The Greening of the WTO" (co-author Michael Weinstein), Foreign Affairs, November-December 2001; "Judicial Independence in the World Trade Organization" in International Organizations and International Dispute Settlement: Trends and Prospects (Transnational Publishers, 2002); "The Law of Environmental PPMs in the World Trade Organization," Yale Journal of International Law, Winter 2002; "The Review of Health Standards in the WTO: A Comment," The Role of the Judge in International Trade Regulation (University of Michigan Press, 2003); "The Appellate Body's GSP Decision," World Trade Review, July 2004; "The World Trade Organization in 2020," Journal of International Law \& International Relations, Spring 2005; Steve Charnovitz, Debra P. Steger and Peter Van den Bossche (eds), Law in the Service of Human Dignity; Essays in Honour of Florentino Feliciano (CUP, 2005); "The WTO's Environmental Progress," Journal of International Environmental Law, September 2007; "Mapping the Law of WTO Accession," in WTO at Ten: Governance, Dispute Settlement and Developing Countries (Juris Publishing, 2008); "The Enforcement of WTO Judgments," Yale Journal of International Law, Summer 2009; "Reviewing Carbon Charges and Free Allowances under Environmental Law and
} 
published in academic books and journals and are available in their original forms and sometimes online. But I recent years, I have had a lot of my writings published on the International Economic Law and Policy Blog, an excellent online forum created by Simon Lester. I have chosen that Blog because it is followed by the WTO community in Geneva and because Blogging provides for immediate publication. Far too often, the lengthy publication times in the academic press mean that by the time policy-relevant scholarship is published, it is already out of date and the opportunity to influence those policies has been missed.

Principles," ILSA Journal of International \& Comparative Law, Winter 2010; "A Post-Montesquieu Analysis of the WTO," in Governing the World Trade Organization (Cambridge University Press, 2011); "The Structure and Function of the World Trade Organization (with John H. Jackson)" in The Ashgate Research Companion to International Trade Policy, (Ashgate, 2012); "US - Tyres: Upholding a WTO Accession Contract -- Imposing Pain for Little Gain," World Trade Review, April 2013; "Green Subsidies and the WTO", Robert Schuman Centre for Advanced Studies Research Paper No. RSCAS 2014/93 For example, see "New WTO Adjudication and its Implications for the Environment," International Environment Reporter, 18 Sept. 1996; "The WTO's Alcoholic Beverages Decision," Review of European Community \& International Environmental Law, 1997; "The World Trade Organization, Meat Hormones, and Food Safety," International Trade Reporter, 15 Oct. 1997; "Environment and Health Under WTO Dispute Settlement," International Lawyer, Fall 1998; "World Trade Organization Turtle Decision Makes Progress," Journal of International Wildlife Law and Policy, 1998; "Improving the Agreement on Sanitary and Phytosanitary Standards," in Trade, Environment and the Millennium (United Nations University Press, 1999; "The Supervision of Health and Biosafety Regulation by World Trade Rules," Tulane Environmental Law Journal, Summer 2000; "The Greening of the WTO," (co-author Michael Weinstein) Foreign Affairs, November-December 2001; "Judicial Independence in the World Trade Organization" in International Organizations and International Dispute Settlement: Trends and Prospects (Transnational Publishers, 2002); "The Law of Environmental PPMs in the World Trade Organization," Yale Journal of International Law, Winter 2002; "The Review of Health Standards in the WTO: A Comment," The Role of the Judge in International Trade Regulation (University of Michigan Press, 2003); "The Appellate Body's GSP Decision," World Trade Review, July 2004; "The World Trade Organization in 2020," Journal of International Law \& International Relations, Spring 2005; Steve Charnovitz, Debra P. Steger and Peter Van den Bossche (eds), Law in the Service of Human Dignity; Essays in Honour of Florentino Feliciano (CUP, 2005); "The WTO's Environmental Progress," Journal of International Environmental Law, September 2007; "Mapping the Law of WTO Accession," in WTO at Ten: Governance, Dispute Settlement and Developing Countries (Juris Publishing, 2008); "The Enforcement of WTO Judgments," Yale Journal of International Law, Summer 2009; "Reviewing Carbon Charges and Free Allowances under Environmental Law and Principles," ILSA Journal of International And Comparative Law, Winter 2010; "A Post-Montesquieu Analysis of the WTO," in Governing the World Trade Organization (Cambridge University Press, 2011); "The Structure and Function of the World Trade Organization (with John H. Jackson)" in The Ashgate Research Companion to International Trade Policy (Ashgate, 2012); "US - Tyres: Upholding a WTO Accession Contract -Imposing Pain for Little Gain," World Trade Review, April 2013; "Green Subsidies and the WTO", Robert Schuman Centre for Advanced Studies Research Paper No. RSCAS 2014/93, Sept. 2014; "Canada - Renewable Energy: Implications for WTO Law on Green and Not-So-Green Subsidies" (with Carolyn Fischer), World Trade Review, April 2015; "What the World Trade Organization Learned from the International Labour Organization" in Research Handbook on Transnational Labour Law (Edward Elgar, 2015); "John Jackson and the GATT's Transformation," 15 World Trade Review 401 (2016); "How American Rejectionism Undermines International Economic Law," Trade, Law \& Development, 2018; "A WTO if you can keep it," Questions of International Law, Nov. 2019; "Grading Trump's China Trade Strategy," European Yearbook of International Economic Law, forthcoming 2019. 
My writings over the past few years on the Blog about the Appellate Body are extensive and may be of use to future scholars who seek to understand how the Appellate Body came to be forsaken. Blogs by their nature are ephemeral and not indexed. Therefore, the purpose of this paper is to preserve my 2016-19 Blog posts regarding the Appellate Body in a form that will be usable by future scholars. These posts are presented in chronological order starting in 2016.

\section{The 12 Blog Posts that I will include are:}

1. The Obama Administration's Attack on Appellate Body Independence Shows the Need for Reforms.

2. How to Save WTO Dispute Settlement from the Trump Administration.

3. A Defense of the Beleaguered WTO Appellate Body.

4. The WTO Appellate Body Crisis: A Critique of the EU's Article 25 Proposal.

5. Comments on the EU's Proposal for Article 25 Arbitration.

6. Comments on the Appellator Graham Affair.

7. The Attack on the Appellate Body- Events of 3 December 2019.

8. The Attack on the Appellate Body- Events of 4 December 2019.

9. The Attack on the Appellate Body- Events of 5 December 2019.

10. The Attack on the Appellate Body- Events of 6 December 2019.

11. The Myth of No WTO Precedent.

12. The Missed Opportunity to Save WTO Dispute Settlement.

1. The Obama Administration's Attack on Appellate Body Independence Shows the Need for Reforms

Steve Charnovitz

22 September 2016

The Obama Administration has not yet apologized for its unilateral action in May 2016 to unseat Appellate Body Member Seung Wha Chang, a distinguished jurist from South Korea. Although this hostile act by the United States has been roundly criticized by other governments 
within the World Trade Organization (WTO) and by many outside commentators, the Obama Administration refused to back down from its action to threaten WTO judges with nonreappointment if their judicial opinions rankle the U.S. Trade Representative (USTR). Ironically, although President Obama has rightly criticized the U.S. Senate for refusing, for political reasons, even to consider the President's mid-March Supreme Court nomination of Judge Merrick Garland even though that inaction leaves one Justice seat vacant, the Obama Administration engages in analogous politicization at the WTO that leaves one Appellator seat vacant.

Although the Obama Administration had refused in 2011 to go along with the widely-supported reappointment of Appellate Body Member Jennifer Hillman from the United States, reportedly on the grounds that she had not upheld U.S. protectionist measures being challenged in WTO dispute settlement, this most recent Obama Administration action to blackball another country's judge is a more serious assault on judicial independence in the WTO. Starting next week (26 September 2016), the WTO Dispute Settlement Body (DSB) is scheduled begin a focused discussion on improving the appointment process for Appellate Body Members. Below I offer a proposal to clarify the Dispute Settlement Understanding (DSU) regarding reappointment.

The Obama Administration announced its decision to block the reappointment of Judge Chang at the May 23 DSB meeting. The reason offered was that the Obama Administration disagreed with the jurisprudence articulated in four recent Appellate Body decisions on which Judge Chang was one of the three appellators on the division deciding the case. Two of those cases involved successful challenges by China against countervailing duties imposed by the Obama Administration. At the DSB Meeting, the Administration stated clearly that Appellate Body jurists needed to be "held responsible" and "accountable for the views they have endorsed" (Statement by the United States at the Meeting of the WTO Dispute Settlement Body, 23 May 2016).

The Obama Administration's announcement elicited an outcry of opposition in the world trade community. According to an account of the DSB Meeting published by the WTO, numerous governments, led by South Korea, either objected to the U.S. position or expressed concerns about the damage that could be done to the WTO. The other complaining governments included Brazil, China, Colombia, Egypt, the European Union, Honduras, Iceland, India, Indonesia, Mexico, Nigeria, Oman, Paraguay, Russia, Switzerland, Taiwan, Thailand, Turkey, Uruguay, and Viet Nam. Based on press accounts (as the official WTO minutes remain classified as of 22 September 2016), no government sided with the United States. (See "U.S. Slammed at DSB For Blocking Korean Appellate Body Reappointment", World Trade Online, 23 May 2016).

By conditioning its support for a judicial reappointment on whether or not a WTO judge sides with the United States on the substance or process of WTO law, the Obama Administration strikes at the heart of the concept of judicial independence. In 1994, when the US Executive Branch sought Congressional approval for US membership in the WTO, the US "Statement of Administrative Action" characterized the new Appellate Body as being composed of "seven 
independent experts" (SAA, p. 345). That Statement of Administrative Action was approved by the US Congress in the Uruguay Round Agreements Act (19 USC §3511). But the WTO appellators can hardly be "independent" when they know that the United States (or any other WTO Member) will veto a reappointment as a way of making WTO judges "accountable for the reviews they have endorsed."

I could not find any position paper on the USTR or White House websites explaining how the Obama Administration decided to target Judge Chang. The Administration did not seek any public comment on its plan to fire Judge Chang, and has not explained why the benefits to the United States from intimidating WTO judges will be greater than the costs to the United States of embarrassing South Korea and undermining the WTO.

The US ouster of Judge Chang was an affront to South Korea. Chang was the first and so far only Korean judge to serve on the Appellate Body. In an article about this sordid episode in the Korea Times (see Choi Sung-jin, "US set to oust Korean judge from WTO appellate body," 1 June 2016), an unnamed Korean government official is quoted as saying "We are explaining the iniquity of the U.S. moves to other member countries." That the Obama Administration singled out South Korea for the harsh judicial treatment should be put in context of the unfair way in which the Obama Administration has treated South Korea in bilateral trade relations. The most egregious conduct involved the Korea-US Free Trade Agreement (KORUS) that had been signed by both countries in 2007. After he took office, however, President Obama refused to send the KORUS to the Congress until Korea agreed to renegotiate the KORUS and accept more US protectionism. In particular, the Obama Administration pressured Korea to allow the $25 \%$ US tariff on imported trucks to remain in place for seven additional years rather than to begin to be phased out in the first year of the trade agreement. One wonders why in view of the increasing militarism in North Korea, the Obama Administration sees geopolitical reasons to embarrass the government and people of South Korea.

The US ouster of Judge Chang was also an affront to the WTO. Already suffering a legitimacy crisis for its inability to complete ongoing Doha Round trade negotiations (owing in large part to weak USTR leadership), the WTO has been enjoying a legitimacy boost from its effective dispute settlement system. But when the Obama Administration forces a vacancy in the Appellate Body and politicizes the process of re-appointment, the future effectiveness of WTO dispute settlement is put at risk.

The danger to the WTO dispute system was immediately grasped by the WTO community. The other six appellators sent a joint letter to the DSB Chair on 18 May 2016 observing that "The dispute settlement system depends on WTO Members trusting the independence and impartiality of Appellate Body Members. Linking the reappointment of a Member to specific case could affect that trust." In addition, the corps of retired WTO appellate judges voiced sharp criticism. In a letter dated 31 May 2016, all 13 former Appellate Body members wrote to the DSB chair to criticize the blocked reappointment. The letter observes that "all of the accomplishments of the past generation in establishing the credibility of the WTO dispute system can be put in jeopardy" by "inappropriate pressures by participants in the WTO system." 
In addition, many WTO scholars have also been critical of the Obama Administration. For example, Professor Gregory Shaffer wrote: "USTR's hubris could be explained if this were Putin's Russia. Or perhaps Trump's America. But the Obama administration? Has this fallen outside the President's radar?" ("Will the US Undermine the World Trade Organization?, 23 May 2016, The World Post).

The Obama Administration's disrespect for the WTO comes at a precarious time in US trade politics when leading candidates in the upcoming elections are calling into question the benefits to the United States from international trade and from WTO Membership. It is not enough for a US President merely to say the right things as President Obama did at the United Nations on 20 September when he declared that "I believe that as imperfect as they are, the principles of open markets and accountable governance, of democracy and human rights and international law that we have forged remain the firmest foundation for human progress in this century." A President must also do the right things. And President Obama failed to do the right thing when he allowed (or ordered) his Administration to undermine judicial independence in international trade law and to unaccountably veto the reappointment of a distinguished Korean jurist supported by most (if not all) other WTO member governments.

The continuing fallout from the US judicial veto calls for a decisive response at the WTO. At the DSB meeting next week, I propose that the Members promulgate new normative guidance on Appellate Body appointments. Happily, a made-to-order statement is available in the excellent letter from the 13 former appellators which states in one pertinent paragraph:

"A decision on the reappointment of a Member of the Appellate Body should not be made on the basis of the decisions in which that Member has participated as a part of the divisions in particular appeals, lest the impartiality, the independence, and the integrity of that one Member, and, by implication, of the entire Appellate Body, be called into question. Nor should either appointment or reappointment to the Appellate Body be determined on the basis of doctrinal preference, lest the Appellate Body become a creature of political favor, and be reduced to a mere political instrument. Rather, as provided in Article 17.3 of the WTO Dispute Settlement Understanding, the standard for both appointment and reappointment should be whether the person in question is 'of recognized authority, with demonstrated expertise in law, international trade and the subject matter of the covered agreements generally'."

A decision adopting this policy statement can be taken in the DSB by consensus pursuant to DSB Article 1.4.

Another reform I recommend is that the Appellate Body should adopt an amendment to its Working Procedures for Appellate Body Review (see WT/AB/WP/6, 2010, para. 2 (Duties and Responsibilities)) to make clear that Appellate Body members should not accept invitations to be interviewed by a WTO member regarding a reappointment. It has come to my attention that USTR's Geneva office has on recent occasion called in a sitting Appellate Body member to discuss her reappointment. Since the US government apparently cannot resist the temptation to engage in WTO-illegal ex parte communication with Appellate Body members, the Appellate Body, by its own rules, should forbid such reappointment interviews. 
In summary, the Obama Administration should apologize to the WTO for the damage USTR has caused and the Administration should support the enactment of a DSB normative statement to depoliticize reappointments of WTO judges.

Posted by Charnovitz on September 22, 2016 at 06:23 PM

\section{How to Save WTO Dispute Settlement from the Trump Administration}

\section{Steve Charnovitz}

3 November 2017

The Trump Administration is trying to torpedo the World Trade Organization (WTO) dispute settlement system. According to the November 2, 2017 Wall Street Journal article "Has China Swallowed the WTO" by Jacob M. Schlesinger, "The Trump administration has escalated the Obama administration's battle over the appellate body, blocking appointments of any new judges and sparking fights even with members sympathetic to the U.S. campaign against China." Schlesinger further explains that at the August 31 meeting of the WTO Dispute Settlement Body (DSB), the United States "said it would block any attempt to fill those slots until 'longstanding' complaints about the court were addressed."

In an earlier post, I reported on the Obama Administration's shameful intervention in 2016 to block the re-election of the judge from Korea. See Steve Charnovitz, "The Obama Administration's Attack on Appellate Body Independence Shows the Need for Reforms," Sept. 22,2016 . Unfortunately, by getting away with that scheme, the US Trade Representative became emboldened to block future appointments to the Appellate Body.

The current WTO judicial elections crisis is even worse as there are now two WTO appellator slots where new members are needed. A third seat on the seven-member Appellate Body will open on December 11, 2017 when the term ends for Prof. Peter Van den Bossche, the distinguished jurist from the European Union. At the most recent DSB meeting for which the WTO has published minutes, on September 29, 2017, the minutes show the United States delegate saying that the United States "could not consider launching a selection process to fill a vacancy on the Appellate Body if the person to be replaced continued to serve and decide appeals." See WTO, Appellate Body matters, September 29, 2017. Under the Appellate Body Working Procedures, appellators actively serving as judges on a particular case have always continued to complete service on that case after their formal term expires.

A vacancy of three of the seven members of the Appellate Body will put WTO dispute settlement into an existential crisis. The shorthanded Appellate Body has already fallen behind its normal processing time in several cases, and with additional judges being eliminated, the continued viability of the DSU Article 17 right to appeal will be in doubt because each appeal must have a division of three appellators. Even worse, the WTO dispute rules (Art. 16.4) delay the adoption of a panel report by the DSB "until after completion of the appeal." So if the Trump Administration's intransigence renders the Appellate Body inutile, that also makes it 
impractical to adopt any panel report because either party to the proceeding could lodge an appeal as a way to stop that case dead in its tracks. That nightmare scenario would effectively put the entire WTO dispute settlement out of business.

The Trump Administration is using this gambit to intimidate other countries to agree to its goals of watering down substantive trade disciplines and rules of WTO judicial procedure. Governments that cherish the international economic rule of law see a hard choice between giving into U.S. protectionist demands and weakening the WTO enforcement system. (See Bryce Baschuk, "WTO Members Fired Up Over Appellate Body Obstruction by U.S," Bloomberg BNA International Trade Reporter, 34 ITR 1418, Oct. 26, 2017.)

Happily a third option exists. The Appellate Body can step in to shore up WTO dispute settlement. Yet time is short because after December 11, there will be only a bare majority of the Appellate Body empowered to make decisions pursuant to Rules 3(1) and 15 of the Working Procedures for Appellate Body Review.

The third option is to amend the Appellate Body's Working Procedures. Article 17.9 of the WTO Dispute Settlement Understanding empowers the Appellate Body to draw up Working Procedures in consultation with the Chairman of the DSB and the WTO Director-General. This authority has been used regularly by the Appellate Body since February 1996. The Appellate Body does not need U.S. consent to amend its Working Procedures.

I propose that the Appellate Body amend Rule 20 of the Working Procedures to state that in the event of three or more expired terms in the Appellate Body membership, the Appellate Body will be unable to accept any new appeals. Although the Appellate Body does not have the right to formally take away the right to appeal, it does have the right to declare in advance that under those extreme circumstances, the "completion of the appeal" will occur automatically on the same day that any new appeal is lodged. In other words, by removing itself from the dispute process for new cases, a disabled Appellate Body will step aside so that the panel decision can automatically be adopted by the WTO Dispute Settlement Body on a timely basis. For a depleted Appellate Body bench to continue processing new cases would necessarily cause huge delays, thus frustrating the Uruguay Round goals of a prompt dispute system. (See Gregory Shaffer, Manfred Elsig \& Mark Pollack, "Trump is fighting an open war on trade. His stealth war on trade may be even more important," Washington Post Monkey Cage, Sept. 27, 2017.) The current docket of the Appellate Body already includes seven appeals that would be pursued to conclusion under my proposal. But no new appeals would be processed after December 11, 2017.

The creation of the second-level review by the Appellate Body was one of the most innovative and successful features of the WTO dispute understanding achieved during the Uruguay Round. Foregoing appellate review would be a loss to the system, but the system could survive it temporarily. While the attack on the independent Appellate Body by the Trump Administration is unfortunate and not easy to fight off due to consensus rulemaking in the DSB, the DSU rules do give the Appellate Body the tools to preserve much of the integrity of the WTO dispute panel system. 
I urge the Appellate Body to erect this defense now before it is too late. By limiting the potential damage to WTO dispute settlement in this way, the Appellate Body could, in effect, call the Trump Administration's bluff as to whether it wants to maintain the option of a United States appeal in future WTO panel decisions.

Posted by Charnovitz on November 03, 2017 at 12:01 PM

\section{A Defense of the Beleaguered WTO Appellate Body}

Steve Charnovitz

9 May 2019

In November 2017, I authored a paper warning that the Trump Administration was seeking to eviscerate World Trade Organization (WTO) dispute settlement. At the same time, I put forward a specific proposal for what the Appellate Body could do to save the Dispute Settlement Understanding (DSU) of the WTO (Steve Charnovitz, "How to Save WTO Dispute Settlement from the Trump Administration, 3 November 2017, https://worldtradelaw.typepad.com/ielpblog/2017/11/how-to-save-wto-dispute-settlementfrom-the-trump-administration.html). My proposal was for the Appellate Body to amend its rules to state that in the event three or more vacant appellator slots existed, that the "completion of the appeal" would automatically occur on the same day that any appeal was lodged. Had the Appellate Body adopted my plan, they could have insulated the WTO dispute system from the impending nightmare scenario of a right of any WTO defendant government to block the adoption of a WTO panel report merely by appealing it to an out-of-business Appellate Body.

Unfortunately, the Appellate Body did not adopt my rescue plan.

Now, over 18 months later, the WTO continues to struggle with the implications of United States rejectionism against the trading system. In recent weeks, I have noticed an increase in new disturbing trends at the WTO. I've seen well-intentioned WTO member governments offering proposals to rewrite the DSU in an effort to appease the Trump Administration.

I had hoped by now that governments had learned that appeasement of authoritarians never works. The Trump Administration is seeking to destroy the international rule of law on trade, and other WTO members should not be accomplices in this mayhem.

There are worse things than losing an Appellate Body or losing the automatic adoption of WTO panel reports.

On 7 May 2019 in Geneva, Trump's Ambassador to the WTO Dennis Shea gave a tough speech to the WTO General Council. The Ambassador's remarks were replete with misstatements of trade law and misstatements of fact. This was par for the course in an Administration that seems to believe that if one repeats a falsity enough, it will become true. 
So far, I have not seen any refutation of Ambassador Shea's spurious assertions. So, for the record, let me debunk them one by one.

Shea's first claim is that there is a DSU rule that "A person who has ceased to be an Appellate Body member may not continue deciding appeals as if his term has been extended by the Dispute Settlement Body." That claim is untrue because the Appellate Body, pursuant to its authority in DSU Article 17.9, enacted Working Procedures back in the mid-1990s that provided for the contingency of an expiration of an appellator term during the pendency of an appeal on which the appellator had been assigned to "serve." This administrative law (Rule 15) allows such an appellator to complete his or her service on that appeal. The Trump Administration has suggested that Rule 15 is ultra vires, but DSU Article 17.1 does not contain any conflicting black letter law that in the event that an appellator term expires, the appellator must resign from a tribunal.

Consider this counterfactual: If the Appellate Body had not written the wise contingency rule (in Rule 15), the Appellate Body would have had to discontinue many ongoing appeals when one of the sitting appellator's term ended. Scotching ongoing appeals might have been convenient for the United States which is the most frequent WTO defendant and the most frequent loser of WTO cases against it. But judicial dissolution would have been a bad outcome for the WTO dispute system.

Second, Shea asserts that there is a DSU rule that "The Appellate Body may not make findings on issues of fact...." No authority was offered for that proposition and certainly the DSU does not forbid the Appellate Body from making incidental statements of fact. Of course, the Appellate Body should not entertain new facts and or substitute itself for the panel's role as the trier of facts. But the Appellate Body has not done so. The DSU does say that appeals "are limited to issues of law," but that basis for appeal should not be understood to prohibit the Appellate Body from addressing the facts necessary to accomplish its mandate "to uphold, modify or reverse the legal findings and conclusions of the panel" (DSU Article 17.13).

Third, Shea asserts that there is a DSU rule that "The Appellate Body may not give advisory opinions on issues that will not assist the DSB [Dispute Settlement Body] in making a recommendation to bring a WTO-inconsistent measure into compliance with WTO rules." While there is no DSU rule stating that proposition exactly, no one would deny that the Appellate Body should not be issuing advisory opinions. But the Appellate Body has not issued such opinions. Thus, Shea's assertion that "the DSU provides for rules, and "those rules have been broken with impunity by the Appellate Body" is false. So is his assertion that the Appellate Body "is disregarding the clear rules."

Fourth, Shea argues that there is a rule that "The Appellate Body may not assert that its reports serve as precedent or provide authoritative interpretations." Certainly, nothing in the DSU prohibits tribunal decisions from being considered as precedent by future tribunals. The entire history of dispute settlement in the General Agreement on Tariffs and Trade (GATT) going back to the early 1950s shows the regular attention by tribunals to precedent. Quite rightly, the Appellate Body has posited that absent cogent reasons, an adjudicatory body will resolve the 
same legal question in the same way in a subsequent case. Consistent with the approach taken by other newly-created international tribunals over the past century, the WTO Appellate Body has sought to clarify its role as a higher-level tribunal in a continuing legal system. As the DSU explains, WTO dispute settlement "is a central element in providing security and predictability to the multilateral trading system" (DSU Article 3.2). Imagine the hypothetical of the Appellate Body stating in its rules that panels should feel free to consider every case de novo and to flout the jurisprudence of the Appellate Body. Certainly, such a disconnected legal system would have failed to provide the security and predictability sought by the United States and other WTO governments who drafted the DSU. Finally, I know of no evidence that the Appellate Body has ever said that is rulings are "authoritative interpretations," and Shea cites no caselaw to that effect.

Fifth, Shea states that "the Appellate Body may not change Members' substantive rights or obligations as set in the text of the WTO agreements." That statement is true as evidenced by DSU Article 19.2. But the Trump Administration's assertion that the Appellate Body has broken this rule is false. The biggest problem the United States has with the Appellate Body is that the United States has lost an obscene number (presently 49) cases against it for violating WTO trade remedy rules. The perennial arguments by the US Trade Representative about the Appellate Body have little to do with WTO constitutional principles. Rather, the behavior of US trade officials can be explained by the longtime US abuse of trade remedies (like antidumping duties) to protect politically connected US industries.

Seventh, Shea asserts that "the Appellate Body must circulate its reports within 90 days of an appeal." Under DSU Article 17.5, the 90-day deadline is real. And it's true that the Appellate Body has in recent years often missed that deadline. But to assert that the Appellate Body is "disregarding" this clear timing rule is a false claim. A missed deadline by the Appellate Body is not an expression of its agency, but rather a manifestation of the principle of necessity. Every time it misses the 90-day deadline, the Appellate Body explains why in advance. The top reason has been the lack of judicial or staff resources.

Under WTO law, WTO members have an obligation to provide the Appellate Body "with appropriate administrative and legal support as it requires" (DSU Article 17.7 emphasis added) and to fill appellator vacancies "as they arise" (DSU Article 17.2) WTO Members have failed to fulfill those two key administrative obligations, and the Appellate Body should not be blamed for those failures.

During the past week in meetings in Washington, DC, I have heard it said several times that the Appellate Body is guilty of "overreaching" and that it is "exceeding its mandate." Such mantras are not true, no matter how often they are repeated. Since 1996, I have examined over 140 WTO Appellate Body decisions. I have discussed many of them in my classes and wrote commentary on more than I wish to remember. Sometimes by my lights, the Appellate Body gets its wrong. But like any independent international or domestic court, the Appellate Body is interpreting and enforcing the law as it sees it. 
It's a myth that the Appellate Body is "overreaching", "coloring outside the lines", "exceeding its mandate" or any of the other similar criticisms being hurled at the Appellate Body by bullies who know that the Appellate Body will refrain from trying to defend itself.

I am happy to defend the Appellate Body. And WTO Member governments need to stand up to the Trump Administration and not cave into its efforts to crush the WTO compliance system.

Posted by Charnovitz on May 09, 2019 at 03:34 PM

\section{The WTO Appellate Body Crisis: A Critique of the EU's Article 25 Proposal}

\section{Steve Charnovitz}

2 June 2019

Recent reports indicate that the EU is proposing to use Article 25 of the WTO's Dispute Settlement Understanding (DSU) to provide a temporary solution to the ongoing crisis in the Appellate Body of not having enough appellators to adjudicate appeals and to render panel reports adoptable (see World Trade Online," EU Moving forward with WTO Appellate Body backup plan", 31 May 2019). Although I have not yet seen any EU paper, the urgency of the matter provides a good reason to begin an analysis of pros and cons of this backup plan.

The crisis in the Appellate Body is that its judicial bench is now down to only three appellators and two of those terms will end in December 2019. With fewer than three appellators, the Appellate Body will not be able to decide appeals. Furthermore, under DSU Article 16.4, any panel decision under appeal is not eligible for automatic adoption until the "completion of the appeal." Thus, without the possibility of appeal, any defendant in a WTO case can block the adoption of a panel report merely by appealing "into the void". Without adoptability of panel reports, the predictability and security provided by the DSU will disappear.

The reason why four of the seven seats on the Appellate Body remain unfilled is that the WTO Dispute Settlement Body (DSB) has failed in its duty under DSU Article 17.2 to fill vacancies "as they arise." The cause of this failure is that since 2017, the United States has been blocking the appointment process. The blocking of appointments was not invented by the Trump Administration -- the prior art came in the blocking of an appellator reappointment by the Obama Administration -- but the Trump Administration perfected the heinous art through the more destructive goal of attacking the tribunal itself rather than just particular judges. See Steve Charnovitz, "How American Rejectionism Undermines International Economic Law," Trade, Law and Development, Winter 2018.

Beginning in 2017, the looming danger of a halt in the adoptability on WTO panel reports led to numerous proposals being offered to address this predicament. My own proposal, published in this blog on 3 November 2017, would have headed off the problem by having the Appellate Body change its rules so as to declare ex ante that whenever the Appellate Body bench fell 
below five judges, then for any appealed case, the "completion of the appeal" would occur on the same day that the appeal was filed. Unfortunately, the Appellate Body did not adopt my solution for reasons that have not been publicly disclosed. Ironically, at a time when the Appellate Body is regularly criticized for "activism," the failure of the Appellate Body to adopt a DSU defense measure is an example of its inactivism. Given the procedural situation in 2017, only the Appellate Body had the power to clear the way for future panel report adoptions even in the worst-case scenario of the number of appellators falling to zero. In my view, the Appellate Body had the last clear chance (and perhaps the duty) to enable the WTO to avoid the worst aspects of the current predicament. To quote Professor Peter Van den Bossche in his recent address to the DSB, "History will not judge kindly those responsible for the collapse of the WTO dispute settlement system."

With the calendar advancing to June 2019, the EU proposal is to utilize DSU Article 25 . Under DSU Article 25, WTO governments can employ arbitration as an alternative to DSU Article 6 panels. Such arbitration requires "mutual agreement of the parties" and DSU Article 25.3 states that parties "shall agree to abide by the arbitration award." Should a party not abide by the award, Article 25.4 provides for enforcement through the regular techniques of compliance review by an appealable panel report and determination of any SCOO (i.e., a suspension of concessions or other obligations) through arbitration.

As a solution to being able to achieve finality in WTO disputes, Article 25 arbitration does not offer any advantages over regular DSU panels. The Article 25 approach works only if there is ex ante agreement of the litigants to use the parallel track. But if litigants can mutually agree to arbitration without appeal, then the same litigants could also mutually agree to enter into a procedural agreement not to appeal the Article 6 panel report and the Article 21 compliance panel report. Staying within the normal panel process offers considerable advantages over ad hoc arbitration as there are already broadly accepted Working Procedures and thus no need to reinvent them for each arbitration. Staying within the regular panel process also provides a proven path for adjudicating and enforcing compliance which is absent in Article 25. (While it is true that if governments abide by an arbitration award there would not be any need for enforcement, it is similarly true that if governments followed WTO rules, then would not be any need for dispute settlement.)

The only advantage offered by Article 25 is to employ it in a way that makes improvements on regular WTO dispute settlement. Specifically, under Article 25, litigants could agree ex ante that the arbitrator may award monetary damages should violation of WTO rules be found and that the monetary award would be rendered in a manner so as to make it eligible for enforcement in domestic courts under the New York Convention (including its defenses). The use of monetary awards and domestic enforceability is not available in DSU panels, and so experimenting with Article 25 in that way would provide value added.

At this point, the best path forward for WTO members that support the rule of law is to sign on to a Non-Appeal Pact (NAP) in advance so as to agree reciprocally not to appeal WTO panel reports during the ongoing crisis. If most of the active DSU litigants were to sign this Pact, the 
ongoing crisis could be mitigated considerably for cooperating countries. (Obviously this Pact cannot resuscitate the Appellate Body; even my own plan of 2017 recognized that there was no back door rescue for the Appellate Body itself.)

To give concreteness to this idea, here is language that has been suggested for such a NAP:

WTO Membership No-Appeal Pact (NAP)

Recognizing that as of 11 December 2019, the Appellate Body of the World Trade Organization (WTO) may no longer have the minimum required number of members to commence an appeal, and

Being desirous to maintain, even in such situation, rule-based WTO dispute settlement and the adoption of WTO dispute settlement reports by the WTO Dispute Settlement Body (DSB) pursuant to the rule of negative consensus as set out in Articles 16.4 and 17.14 of the Understanding on Rules and Procedures Governing the Settlement of Disputes (DSU),

We agree:

To refrain from appealing a panel report in a dispute where all of the other parties in the dispute are signatories to this No-Appeal Pact;

That this Pact will go into operation on the date that the number of Appellate Body members falls below three and will end on the date that the number of Appellate Body members rises above four; and

That this Pact is an informal understanding of representatives of the Members and does not alter the rights and obligations of the Members.

Signatories:

Posted by Charnovitz on June 02, 2019 at 02:45 PM

\section{Comments on the EU's Proposal for Article 25 Arbitration}

Steve Charnovitz

6 June 2019

This is a follow-up to my earlier post "The WTO Appellate Body Crisis - A Critique of the EU's Article 25 Proposal." See <https://ielp.worldtradelaw.net/2019/06/the-wto-appellate-bodycrisis-a-critique-of-the-eus-article-25-proposal.html>.

Thanks to Tom Miles for posting the Draft 5.16.19 document that the EU has circulated to the WTO for an Interim Appeal Arbitration Agreement based on DSU Article 25. 
The draft agreement would be entered into bilaterally by the EU and another WTO member to agree to resort to arbitration under DSU Article 25 for appeals of final WTO panel reports in the event that the Appellate Body is not operational. The appeal to the arbitral panel would be instead of Appellate Body review. The EU paper contemplates using the Director-General (DG) to appoint three former Appellate Body members to hear the appeal and to use the Appellate Body Secretariat for administrative and legal support. Such duties for the DG and the Appellate Body Secretariat are not contemplated in the DSU, but seem reasonable to me.

Although the EU has shown creativity with its CETA Investment Court, I am less impressed with the idea of an ad hoc appellate tribunal composed of retired appellators. Using former Appellate Body judges is not the same thing as having an Appellate Body with collegiality to hand down decisions. I am not aware of any precedent for replacing an appellate tribunal with ADR of retired judges. I think this idea devalues the idea of an appellate jurisdiction. I don't see why the second panel of three arbitrators should be viewed as more authoritative than the first panel. I am not aware that the EU currently offers an ADR fast track to its European Court of Justice. I would not want to see the Appellate Body permanently replaced by ad hoc ADR, or for that matter an ad hoc judicial machine learning apparatus in the event that three retired Appellate Body members were not available.

Posted by Charnovitz on June 06, 2019 at 03:58 PM

\section{Comments on the Appellator Graham Affair}

Steve Charnovitz

\section{December 2019}

A report on World Trade Online this afternoon states that Appellate Body Chair Thomas Graham is threatening to resign from the Appellate Body when his term ends on December 10 unless the WTO ousts the Mr. Werner Zdouc, the accomplished and respected Director of the Appellate Body Secretariat.

I hope that this report is not true.

Back in September, this Blog featured a report that Mr. Graham was threatening to resign unless the WTO moved to adopt changes in DSU rules that addressed criticisms by the US.

In response, on 26 September 2019, I posted the following comment on the Blog:

"I have no problem with Graham quitting on December 10. He signed on for 8 years and the 8 years are almost over. It's not his fault that the US government has blocked a replacement for him. The replacement should have been agreed to months ago so that the new member could have been available on December 10. I would object to Graham's reported statement that whether he stays or not depends on whether the WTO adopts reforms. It is clearly inappropriate for Appellators to insert themselves into WTO negotiations. I have also taken 
note of Appellate Body Rule 2(3) which states 'A Member shall exercise his/her office without accepting or seeking instructions from any international, governmental, or non-governmental organization or any private source.' In my view, an Appellate Body member who cannot abide by that requirement should not continue to serve on the Appellate Body."

In response to my comment, on 28 September, Mr. Graham posted on the Blog:

"The remark about Rule 2(3) requires a reply. When I joined the AB eight years ago, I said I would never take a position because it was a position of my government, but equally, I would not be intimidated out of taking a position that coincided with that of my government, if I believed the position was correct. I have lived by that principle and continue to do so in the present circumstances. It would be more constructive to address my positions on their merits, instead of by insinuation."

At that time, in late September, out of respect for the court, I decided to give Mr. Graham the last word.

But with the latest news, the time has come to address Mr. Graham's statements on the merits.

As I said back in September, I have no problem with a decision by Mr. Graham to step down on December 10. He has no obligation to stay on if he doesn't want to see his ongoing cases to conclusion. As I said, it's not his fault that a new appellator is not on deck to take over his seat on December 10 under Rule 13.

But I do have a problem with Appellate Body members seeking to insinuate themselves into the international legislative process by unilaterally lobbying for particular changes in WTO rules or for a particular timetable to make legislative changes. The role of the WTO appellate judge is to remain impartial in deciding cases and to avoid taking any political positions within the WTO. On the merits, WTO judges should stay out of WTO negotiations unless their technical advice is specifically requested by negotiators.

As to the directorship of the Appellate Body secretariat, while I am not familiar with the customary practices for the selection of Appellate Body staff, I presume that the Appellate Body should have some say in the Director's post. With only three appellators in place, however, the Appellate Body lacks a quorum to act on personnel matters. (Indeed, in the present circumstances, I question the assumption that an Appellate Body member whose term has expired can complete any appeal under Rule 15 because gaining the authorization of the Appellate Body is a prerequisite for such an extension of service.) Therefore, I see no reason for the WTO Director-General to take any guidance regarding Mr. Zdouc from Mr. Graham. Indeed, if the report is true that the Director-General has resisted pressure from Mr. Graham to oust Mr. Zdouc, then I commend the Director-General for providing yet another example of his continuing strong and enlightened leadership. 
Werner Zdouc is a distinguished international civil servant and he deserves better than to be held hostage to the continuing assaults by the Trump Administration on world trade and international law.

Posted by Charnovitz on December 02, 2019 at 08:45 PM

\section{The Attack on the Appellate Body- Events of 3 December 2019}

\section{Steve Charnovitz}

I was delighted to see the open letter from two current and one former member of the Appellate Body disputing yesterday's news item that various Appellate Body members are seeking the ouster of the Director of the Appellate Body Secretariat.

When I wrote my post yesterday "Comments on the Appellator Graham Affair" I directed my remarks only to Graham and not to any of the other Appellate Body members who were mentioned in the news item. I am not surprised to hear that the news item contained misrepresentations and misinformation. To repeat what I said in my post yesterday, I hope that the allegations about Graham are also untrue.

The rapid denials by three appellators (not including Graham) should be another reminder to the WTO community of how successful the Appellate Body experiment has been. Looking back to 1995 , the individuals elected by the WTO to be appellate judges have served with distinction and honor. I can't think of any international court where the quality of judging overall has been as good as it has been on the Appellate Body.

Therefore, I am constantly amazed at the public relations success of the Trump Administration in getting its anti-Appellate Body narrative accepted, in the absence of any evidentiary basis. It is now a commonplace that Appellate Body members go to work every morning thinking about how they can exceed their mandate, engage in judicial overreach, deny rights, and add obligations. The Trump Administration has accused the Appellate Body of becoming a rogue organization that routinely breaks the rules and people who should know better assume that the Administration is telling the truth. If the Trump Administration's story is to be believed, the WTO appellators perform so badly in their role that they operate beyond the pale of how national or international judges perform. And the most remarkable charge in the US indictment of the runaway Appellate Body is that for 24 years WTO members persist in selecting by consensus new WTO judges who immediately begin to commit the identical judicial errors (such as following precedent) that were made by the previous judges on the Appellate Body.

For the Trump Administration, the WTO Appellate Body was an ideal target to bully and denigrate because WTO appellators would behave as international judges and not fight back. But why have the supporters of the rule of law not fought back? 
8. The Attack on the Appellate Body-Events of 4 December 2019

Steve Charnovitz

At today's DSB meeting, press reports state that the US representative "charged that China and the EU, in calling for the continued use of Rule 15, were supporting what the U.S. sees as the Appellate Body's blatant rule breaking." In addition, the US representative was reported to have complained that "we have heard today statements actively encouraging the Appellate Body to continue to break the rules set out in the DSU." Such USTR arguments, if they were actually made, demonstrate clearly the tendency of the Trump Administration to project its own addiction to rule breaking onto others and to improperly accuse judges and courts of breaking rules.

As the representative from China carefully and thoughtfully explained at the DSB today: Rule 15 "is in conformity" with the DSU and "has been applied on a number of occasions for over twenty years. These precedents have established a routine and customary practice agreed on by all WTO Members which, prior to the end of August 2017, the United States had never objected to."

The Trump Administration, of course, is free to change the US government's position regarding the validity or appropriateness of Rule 15. But as with any action by the Trump Administration, one has to ask what the motive would be in changing the US position so many years after the working procedure was established. Plainly, the motive of the USTR in raising this sham objection regarding the Appellate Body was to justify the false accusation that the Appellate Body has acted ultra vires.

The more the Trump Administration takes outlandish positions at the DSB, the more the United States will marginalize itself in the vital work of the WTO.

Posted by Charnovitz on December 04, 2019 at 08:14 PM

\section{The Attack on the Appellate Body- Events of 5 December 2019}

\section{Steve Charnovitz}

A story on World Trade Online by Hannah Monicken just crossed my desk in which she wrote: "Even those who do not view Zdouc as part of the problem could begin to view his now-public divisiveness as a reason he should go, according to one source -- especially if (sic) would be key to appeasing the U.S. and getting the Appellate Body back in business."

The idea of "appeasing" the US government prompts me to take note of some guidance that I have offered numerous times over the past two years and memorialized recently in my essay "A 
WTO if you can keep it" published 30 November 2019 http://www.qil-qdi.org/a-wto-if-you-can-keepit/

Let me restate the guidance here:

"Both in the workshops and in the public fora, the key advice I constantly offer is that other WTO members should not make the situation worse by offering to appease the Trump Administration. As history has shown, the appeasement of dictators never works."

As a longtime USTR watcher, I can assure everyone that firing Werner Zdouc is not going to appease the Trump Administration regarding the WTO. It won't move the ball on issues such as reappointing 8 WTO appellate judges or getting multilateral trade negotiations moving forward.

In my Blog posting of 2 December "Comments on the Appellator Graham Affair," I discussed the shameful efforts to oust Mr. Zdouc, the Appellate Body (AB) Secretariat Director.

Amazingly to me, one respected trade law scholar commented "I agree, but to sacrifice the $A B$ in order to save the job of one person (or even out of principle) also appears shortsighted."

Let me briefly respond by stating what should be obvious in an international legal system. Acting out of principle is what makes such systems work. Resisting extortionist demands to remove Mr. Zdouc is a step that will help preserve the rule of law at the WTO. If the $A B$ is to be sacrificed on the altar of Trumpism, then let it be sacrificed. But one should not commit acts of injustice as a way of trying to save a judicial system.

Posted by Charnovitz on December 05, 2019 at 08:22 PM

10. The Attack on the Appellate Body-Events of 6 December 2019

Steve Charnovitz

The WTO community is abuzz about a draft Decision that is slated to be considered by the WTO General Council on Monday. The Decision on "Functioning of the Appellate Body" is posted on the WTO portal.

The Decision is designated as an Article IX:1 decision of the General Council acting between meetings of the Ministerial Conference. Here I might note that contrary to WTO rules, the Ministerial Conference has failed to meet as required in 2019.

The WTO Agreement in Article IX:1 provides for decisions by the Ministerial Conference and General Council that can be taken by a majority vote. The precise scope of the competence to issue such decisions with legal effect is not delineated in the WTO Agreement. Many years ago, I pointed out that there surely is some competence (see Steve Charnovitz, "The Legal Status of the Doha Declarations", JIEL, March 2002). But there are also some limitations. For example, 
Article IX:1 authority cannot be used to issue authoritative interpretation of the WTO Agreement or to amend the WTO Agreement.

The Draft Decision reads as if it is meant to have legal effect. For example, it starts with "transitional rules" (emphasis added) for outgoing Appellate Body members. The Draft Decision announces a number of policies "to enhance the functioning" of the DSU. In some instances, the announced policy is already reflected in DSU rules. For example, paragraph 18 repeats the rule and mantra that panels, the Appellate Body, and the DSB cannot add to or diminish rights and obligations. In other instances, the Decision seems to assert a new rule. For example, paragraph 5 would preclude the Appellate Body from assigning an appellator to a division if there is less than 60 days remaining in that appellator's term. And in several instances, the Decision simply makes an observation (for example, paragraph 16) that may or may not be true.

The intent of the Decision seems to be to bow to many of the demands of USTR by imposing new limits on the Appellate Body. For example, the Decision (para. 6) limits the ability of an Appellate Body member serving on a division at the time that her term expires from completing work on the appeal. The Decision (paras 7 and 8) limits the Appellate Body from taking more than 90 days to complete an appeal without approval of the parties. The Decision (para. 11) prohibits the Appellate Body from engaging in the "complete the analysis" practice although the Decision does not clearly state what it means by that. The Decision (para. 13) prohibits the Appellate Body from ruling on issues that have not been raised by either party. In my view, these limitations on the Appellate Body are properly viewed as amendments to the DSU or as authoritative interpretations. I find it hard to square these limitations with WTO Article IX:1 authority as it applies to the General Council convened as the DSB.

Despite the goal stated by the Decision to "enhance the functioning" of the DSU, I believe that by dignifying and giving into the invalid criticisms of the US government, the result of the Decision would be the exact opposite. That is, the Decision would undermine the functioning of the DSU. For example, Paragraph 15 declares that "Precedent is not created" through the DSU. If the purpose of this normative statement is to say previous cases have to be irrelevant to panels, arbitrators, and appellators, then this clearly would undermine the functioning of the DSU or any legal system. On the other hand, a statement that previous decisions are not binding precedent would be consistent with WTO jurisprudence.

Thus far, I have identified two problems with the Decision: first, that it may be legislative overreach under Article IX:1 authority and second, that the substance of the actions may undermine the functioning of the Appellate Body. The biggest problem with the Decision, however, is that it is not stylized as a decision of the DSB. If the DSB were to enact this Decision, it would have to do so by consensus (see WTO Agreement footnote 3). So, I think what is going on is that the DSB is being bypassed so that the authors of this Decision can seek to get it enacted by a majority vote rather than consensus. That is the most serious flaw with the Decision. The goal seems to be to enact a Decision responsive to the (bogus) US complaints and to do so through a procedure that does not require US support. 
The proponents of this Decision are playing a dangerous game. The never utilized authority in DSU Article IX:1 to proceed with majority voting is a precious constitutional resource that should not be wasted on an unnecessary and ill-considered initiative. Even worse, by using majority voting for the first time on a matter that clearly is ineligible for majority voting (because it falls within the jurisdiction of the DSB rather than the General Council), the WTO would be disregarding the rule of law.

Posted by Charnovitz on December 06, 2019 at 09:46 PM

11. The Myth of No WTO Precedent: The Attack on the Appellate Body-Events of 9 December 2019

Steve Charnovitz

Today in Geneva, the US ambassador to the WTO, Dennis Shea delivered a Statement to the General Council that was posted on the US Mission portal.

His Statement is replete with misstatements.

I hope that WTO member governments thoroughly debunked Shea's Statement today at the General Council.

I don't have the time this evening to respond to every falsehood in Shea's new statement. But let me to respond to one aspect of Shea's Statement which has been a persistent element in USTR's false narrative about the Appellate Body and WTO dispute settlement. That is, USTR's assertion that recourse to precedent by the Appellate Body and the panels is improper. For example:

--Shea says that WTO governments "agree that 'precedent' is not created through WTO dispute settlement." reports...."

--He objects to the fact that Appellate Body decisions "assert a precedential value for its

--He claims that regarding its use of precedent, the "Appellate Body has relied on the reference in the DSU to security and predictability to justify its 'cogent reasons" approach."

--He suggests that "some Appellate Body members view themselves as "appellate judges"... serving on a "World Trade Court" that is the "centerpiece" of the WTO dispute settlement system ...rather than one component of it. Such an expansive vision of the Appellate Body is not reflected in the DSU and was not agreed to by the United States."

--He argues that "there has been no discussion of why the Appellate Body has departed from its agreed role." 
Let's start with the myth that WTO tribunals are committing legal error by utilizing precedent and that US government expected or wanted WTO jurisprudence to be precedent-free.

Using precedent is a hallmark of any legal system both ancient and modern. Reliance on customary practices was the central feature of transnational Merchant Law beginning in the Middle ages and attention to precedent and caselaw is part of the history of the development of modern commercial and maritime law.

In the United States, domestic courts regularly make use of the precedential value of previous cases. In its very first case in 1791, West v. Barnes, the US Supreme Court's (unreported) opinion is said to have taken note of the caselaw of state courts and English courts. In its very first case in 1980, the US Court of International Trade (American Schack Co. v. United States) cites numerous prior customs court and appellate decisions.

International courts also use and rely upon precedent. For example, early decisions of the Permanent Court of International Justice (PCIJ) cited previous decisions in the same court. For example, in the Mavrommatis Jerusalem Concessions case (1925), the PCIJ refers to a previous PCIJ decision (see pages 21, 26). In the Factory at Chorzow case (1927), the PCIJ refers to two of its previous decisions (see pages $5,9,12,20,24,26,27,28,30$, and 31). The same judicial practices unabashedly continued into the International Court of Justice (ICJ). For example, in its first case in Corfu Channel (1948), the ICJ cited a PCIJ decision on the same point (see page 28).

Given the longtime use of precedent in other international law tribunals, the use of caselaw became a hallmark of the dispute system of the General Agreement on Tariffs and Trade (GATT). This did not occur immediately, but got into full swing by the mid-1970s. For example, in 1976, the GATT panels adjudicating four tax cases involving the United States as either a plaintiff or defendant considered previous GATT caselaw. In all four of these cases (involving defendants Belgium, France, the Netherlands, and the United States), at the end of the panel's analysis, the panel stated: "In the light of the above, and bearing in mind the precedent set by the Uruguayan case (BISD 11 Supp. p. 100), the panel found...." All four of these decisions were adopted with USTR approval by the GATT Council in 1981 subject to an Understanding. (In my view, the Appellate Body in February 2000 gave short shrift to this 1981 Understanding; while I have criticized that Appellate Body decision over the years, there is a world of conceptual difference between criticizing a particular judicial ruling and accusing the court of overreach or underreach. For the USTR of today, losing a WTO claim is never because USTR argued it poorly or because it was a bad claim; rather for USTR, losing a WTO claim is to be blamed on misbehavior by the WTO tribunal.)

When the WTO dispute settlement began in 1995, WTO panels continued the customary practice of GATT panels of utilizing prior caselaw. In my view, WTO tribunals acted in this way not just to achieve the DSU Article 3.2 goals of "security and predictability." Rather, WTO panels were also following the mandate set by consensus by the GATT member governments who wrote the WTO Agreement. To wit, Article XVI:1 of the WTO Agreement calls for the WTO be "guided by the decisions, procedures, and customary practices" followed in the GATT. In the false narrative purveyed by the Trump Administration, it is said that the US government never 
agreed to a "vision" that caselaw should have "precedential value" for WTO panelists or appellators. Neither Ambassador Shea nor USTR, to my knowledge, has ever offered any evidence for this ridiculous assertion.

In fact, all of the evidence is on the other side of the argument. If WTO panels were not supposed to consider prior caselaw, then why did USTR in the very first WTO case, US - Gasoline (1996), seek to buttress its arguments by citing a previous GATT panel ruling (see para. 3.62). Why did USTR in lodging the US v. Japan Alcohol case (1996) cite prior caselaw in making its arguments (see paras. 4.7, 4.18, 4.27, 4.29). And when it argued before the Appellate Body in Japan - Alcohol, why did USTR cite a GATT panel case as authority (see pages 4-5). And when it argued as plaintiff before the Appellate Body in Canada - Periodicals, why did USTR cite three previous Appellate Body reports (see pages 12-13) as authority? The answer is that the United States in 1995-97 was comfortable with asking WTO tribunals to hand down decisions based on prior caselaw.

Today, the Trump Administration is uncomfortable with the way that judicial precedent is being used in domestic and international courts to find violations of law by the Trump Administration and the United States. I can understand their embarrassment that so many domestic and international judges are properly ruling against them. But losing cases at the Appellate Body does not in any way justify the shameful and cowardly attack by the Trump Administration on the Appellate Body. The truth is that if the Trump Administration were not engaging in so many protectionist, mercantilist, and other abusive non-market practices, then it would not be losing so many WTO cases against the United States.

To be sure, there can be valid differences in the ways that various legal systems and various courts use their own caselaw and the caselaw of other courts. One can debate in what circumstances judicial precedent is, or should be, binding upon a court. With respect to the WTO, the Appellate Body has never held its own precedent to be legally binding on it or on WTO panels. In my understanding of the Appellate Body's (quite limited) "cogent reasons" jurisprudence, the Appellate Body is suggesting that its caselaw is not legally binding on panels and that panels have a right to fail to follow Appellate Body precedent if the panel has a cogent reason for doing so. Of course, the Appellate Body would then have the authority to reverse the panel for a legal error if the Appellate Body did not agree with the cogent reason.

At the General Council, Shea lamented that there "has been no discussion of why the Appellate Body has departed from its agreed role." The truth is that the Appellate Body has not departed from the role assigned to it in the DSU. For years now the Trump Administration has intentionally perpetrated a myth that the Appellate Body has operated outside the lines of what governments expected in 1994 when the Appellate Body was written into the DSU. Contrary to that myth, the creation of the Appellate Body was such a novel and innovative achievement in international law that WTO member governments did not express and could not have had any precise legitimate expectations as to how the legal experiment would play out. The very essence of an appellate court is to exercise supervision over a lower court. In such uncharted waters, the Appellate Body had to write its rules and establish its 
customary practices by drawing on analogies from national law systems and from other international courts that act as agents of governments. As I wrote in my 2005 article The World Trade Organization in 2020, the early Appellate Body did a darn good job in helping the WTO achieve the hopes of many generations of trade supporters for a better international rule of law in trade.

In my scholarly writings and in my teaching of trade law, I do sometimes refer to the WTO dispute settlement system as a "World Trade Court." I know that USTR does not like that term, but their problem with it is more the first two words than the third.

When it was established in 1995, the WTO was endowed with the best architecture for compliance review and enforcement of any international organization. The Trump Administration's attack on the Appellate Body has now disabled the extraordinary achievement in the WTO to have operated a cutting edge and effective dispute and implementation system for the past 25 years. In looking at the havoc that USTR has wreaked on the WTO, I am reminded of the adage of longtime U.S. Speaker of the House Sam Rayburn: "Any jackass can kick a barn down, but it takes a good carpenter to build one." The WTO dispute system was built by good carpenters from around the world including in USTR in the early 1990s as led by Ambassador Carla Hills and Ambassador Mickey Kantor. For US trade policy today, sadly, the good carpenters are gone.

12. The Missed Opportunity to Save WTO Dispute Settlement: The Attack on the Appellate Body - Events of 10 December 2019

\section{Steve Charnovitz}

Today, the Standing Appellate Body was felled by the attack of the Trump Administration. By making appellate adjudications impossible, the Trump Administration is now empowered to strategically appeal any WTO panel decision against the US knowing that such appeal will prevent the panel report from being adopted. The Trump Administration may not appeal every panel decision, but they will surely appeal any compliance panel decision holding against the US.

This is a serious blow to the rule of law in the world trading system.

I did my best to head this off this looming disaster over two years ago when I posted the article "How to Save WTO Dispute Settlement from the Trump Administration" https://worldtradelaw.typepad.com/ielpblog/2017/11/how-to-save-wtodispute-settlement-from-the-trump-administration.html. My solution was for the Appellate Body to immediately announce that whenever three or more vacancies exist on the Appellate 
Body, no new appeals would be accepted. This result could have been accomplished by adopting a new DSU Article 17.9 Working Procedure stating that the "completion of the appeal" under DSU Article 16.4 would "occur automatically on the same day that any new appeal is lodged." This solution would have enabled the DSB to move ahead with the adoption of WTO panel reports without benefit of a second-level review.

My recent essay "A WTO if you can keep it" presents the history of the trading system as context for discussing the campaign of the Trump Administration to checkmate international trade law. One part of my essay tells the story of my rescue plan and provides a legal analysis of it. My essay was published in November 2019 on QIL at http://www.qil-qdi.org/a-wto-if-youcan-keep-it/. An abstract appears on SSRN at https://papers.ssrn.com/sol3/papers.cfm?abstract_id=3498574.

The WTO would not have suffered today's damaging blow if the Appellate Body had adopted my solution while there was still time to do so. The optimal window for the Appellate Body to have acted began on 4 November 2017 (the day after I posted my article) when there were only two appellator vacancies. The optimal window for action ended on 11 December 2017 when a third appellator vacancy occurred. Less optimally, the Appellate Body could have adopted my proposal up to 30 September 2018 when a fourth vacancy ensued and the Appellate Body lost its judicial quorum (i.e., 4 of 7) for adopting new rules.

I am often asked how events would have played out if the Appellate Body had taken my advice. In this essay, I answer that question by laying out a ceteris paribus scenario of what would have happened if the Appellate Body had erected my proposed safety net on 10 December 2017 (the last day where there were five appellators in place). I call this alternative future the "Saved DSU Scenario." In this scenario, the Appellate Body would have stopped accepting new appeals on 12 December 2017 after the number of appellators had fallen from 5 to 4 .

Nothing would have happened until late February 2018. On 22 February 2018, the panel in the Japan v. Korea Radionuclides case (DS 495) issued its decision. This panel found SPS violations by South Korea. In real life, the panel report was appealed on 9 April 2018, and on 26 April 2019, the DSB adopted the Appellate Body report which narrowed the ruling against Korea. In my Saved DSU Scenario, the panel report would have been adopted as it was by 22 April 2018 (i.e. within the mandated 60 days). So, the result would have still been Korea losing, but that result would have occurred over a year earlier. When the panel report went to the DSB in April 2018, there would have been a debate as to whether the action by the Appellate Body to withhold substantive consideration of the appeal was proper. After that debate, the DSB would have adopted the panel report under reverse consensus. In order to refuse the adopt the panel report, the DSB would have needed a consensus and that would have been impossible to obtain.

The next dispute to get to the DSB would have been the compliance panel in US - Countervailing Duty Measures on Certain Products from China (DS 437). This panel report was issued on 21 March 2018. Although the panel rejected some claims by China, the panel found 
that in several instances, the US government was still failing to comply with the WTO's rules on countervailing duties (CVDs). In real life, the panel report was appealed by the US on 27 April 2018. Thereafter, on 15 August 2019, the DSB adopted the Appellate Body report which upheld the panel report. In my Saved DSU Scenario, the panel report would have been adopted by 21 May 2018 with the exact same result that ensued over a year later in August 2019. The cause of justice would have been better served with that more rapid timetable.

When the CVD compliance panel report went to the DSB in spring 2018, a fiery debate would have ensued. The US government would have harrumphed that its right to appeal was being denied by the Appellate Body in yet another example of how the Appellate Body oversteps its mandate. Angrily, the US government would have argued that the DSB lacks authority to adopt the panel report. Other governments would have responded that the reason why the Appellate Body was unable to adjudicate the appeal is because the US government, for over a year, had been illegally blocking the filling of vacant appellator seats. Following that debate, the DSB would have acted by reverse consensus to adopt the panel report. It would have been that easy!

Thereafter, two more appealed cases would have come to the DSB. First, the panel in the Japan v. Korea - Pneumatic Valves case (DS504) would have issued its report on 14 April 2018 finding antidumping violations by Korea. In real life, the panel report was appealed, and then on 30 September 2019, the DSB adopted the Appellate Body report which made technical modifications to the panel report while reaching nearly the same conclusions. In my Saved DSU Scenario, the panel report would have been adopted over a year earlier by 14 June 2018 with nearly the same result that ensued in September 2019. Second, the panel in the Russia v. Ukraine - Ammonium Nitrate (DS 493) case would have issued its report on 29 May 2018 finding antidumping violations by Ukraine. In real life, the panel report was appealed, and then on 30 September 2019, the DSB adopted the Appellate Body report which upheld the panel. In my Saved DSU Scenario, the panel report would have been adopted over a year earlier by 29 July 2018 with the same result that ensued over a year later in September 2019.

Besides those four cases, no further cases appealed after 11 November 2017 have been completed so as to be eligible for adoption by the DSB.

Since May 2018, 14 panel reports have been issued that were appealed. For all these appeals, the appealing governments were on notice that their appeal was unlikely to be decided. Nevertheless, these governments appealed anyway. In some instances, the appeals may have been bad faith appeals principally intended as a way to prevent the adoption of the panel reports. (One of these 14 appeals has now been withdrawn). In my Saved DSU Scenario, either these panel reports would not have been appealed or, if they were appealed, the appeal would have been dismissed. Then all of these panel reports would have been adopted in the same customary manner as the four cases discussed above.

I will not take the reader through all 14 cases. But to highlight a few of them, the US appealed Super calendared Paper (DS 505) in 2018 after losing this CVD case; the US appealed Pipe and Tube (DS 523) in 2019 after losing this CVD case; Canada 
appealed Differential Pricing Methodology (DS 534) in 2019 after the panel issued a narrow ruling against the US in an antidumping case; the US appealed Renewable Energy(DS 510) in 2019 after losing this case under GATT. At the DSB, the US would have objected to the adoption of Super calendared Paper, Pipe and Tube, and Renewable Energy, but those panel reports would nevertheless have been adopted months ago rather than remaining in limbo inside the Appellate Body. The DSB debate on Differential Pricing Methodology would have been interesting because, on the merits, Canada had strong grounds to appeal. But regardless of those legal merits, following the debate, the DSB would have adopted that panel report. Another case that would have played out was Russia v. EU Energy Package (DS 476), a GATT and GATS case, in which the EU appealed in 2018 after the panel vindicated several of Russia's claims while ruling against other claims. After the EU appealed, Russia also appealed. In my Saved DSU Scenario, either the panel report would not have been appealed or, if it were appealed, the appeal would have been dismissed and then the panel report would have been adopted by the DSB in 2018.

In summary, there are now 13 appealed cases at the Appellate Body which may never be adjudicated. In my Saved DSU Scenario, 11 of these panel reports would have already been adopted -- six of them in 2018 and five of them in 2019. Two of those 13 panel reports, against India and the EU, have been appealed within the past month and therefore would probably not yet have been brought to the DSB for adoption. Given current circumstances, both the EU and India appeals are strategic, bad-faith appeals that warrant dismissal.

In my Saved DSU Scenario, the DSB would have continued to be able to adopt all panel reports throughout 2018 and 2019. No interruption of the predictability and security of the WTO panel process would have occurred. Going forward from today, there would not have been any need to seek patches and workarounds because appeal would have been temporarily taken off the table by the Appellate Body in late 2017 until such time as the US allowed the DSB to refill the vacant seats on the Appellate Body. The core part of WTO dispute settlement would have been saved. The WTO would have enjoyed a soft landing rather than suffering a constitutional crisis.

To be sure, the Saved DSU Scenario was unable directly to prevent the demise of the Appellate Body. But that result is no different than what has eventuated in real life. The Appellate Body itself could not be saved from the Trump Administration. But the Appellate Body could have saved WTO dispute settlement from the Trump Administration.

Had the Appellate Body followed my suggestion in December 2017, it could have focused its efforts on the six appeals that were in chambers at that time and issued decisions much sooner. To wit, the appeal in EU - Aircraft (Art. 21.5) was lodged on 13 October 2016 (sic), but was not decided until 15 May 2018. The appeal in US - Aircraft (Article 21.5) was lodged on 29 June 2017, but was not decided by the Appellate Body until 28 March 2019. The appeal in EU - PET was lodged on 30 August 2017, but was not decided until 10 May 2018. The appeal in Brazil - Taxation was lodged on 28 September 2017, but was not decided until 13 December 2018. The appeal in Indonesia - Iron and Steel was lodged on 28 September 2017, but was not 
decided until 15 August 2018. The appeal in US - Tuna II (Second Recourse to Article 21.5) was lodged on 1 December 2017, but was not decided until 13 December 2018.

In short, under my solution, by dismissing all new appeals after 11 December 2017, the Appellate Body could have moved closer to meeting its 60-day deadline through more rapid processing of its backlog of cases. There would have been plenty of work for the Appellate Body to do through March 2019. After March 2019, under my proposal, the three remaining appellators would have had a much lighter inbox. In my view, sparing them the cases appealed after 11 December 2017 would have been more appropriate than piling on numerous new cases which the remaining appellators cannot possibly adjudicate in 60 days.

Even with just the one appellator left today, some WTO governments will continue to appeal. In fact, even a completely empty Appellate Body bench will not stanch the appeals. That's why I posited in November 2017 that there needed to be a common sense connection between the percent of appellators available and the willingness of the Appellate Body to accept new appeals. My proposal, in effect, was that if less than 70 percent of the appellator seats were filled, then the Appellate Body should proclaim itself closed for new business until the missing judges were replaced.

Having laid out this ceteris paribus Saved DSU Scenario, I want to point out that in my original Blog post in November 2017, I suggested that all other things would not be equal. That is, rather than just a static scenario, there could have been a dynamic scenario leading to an even better WTO future. The thought I expressed was that if the Appellate Body adopted my simple rescue plan and demonstrated to the Trump Administration that while the US could kill the Appellate Body, the US could not kill the automaticity of the adoption of WTO panel reports, there could have been a positive behavioral adjustment in the Trump Administration. I said at the time, and I still believe, that if the Appellate Body had outwitted and outflanked the Trump Administration, the Administration would have backed down in blocking Appellate Body appointments. The jig would have been up, so to speak.

The Administration's purpose in emptying out the Appellate Body is not principally to prevent second level appellate review because as many commentators have noted, such review benefits the US as much as anyone. Rather, the Administration's purpose is to immunize the US from accountability in the WTO regarding the protectionist and nonmarket trade policies of the Trump Administration. The US assault on the panel report adoption process also knocked the WTO off balance, thereby helping the Trump Administration thwart the WTO's legislative mission of opening markets and promoting the rule of law.

Today, the Saved DSU Scenario looks pretty good compared to the status quo. But my rescue plan could have enabled an even better future outcome. I will call it the Dynamic Scenario. In this scenario, after it was demonstrated to the US in May 2018 that panel reports would continue to be adopted in the future just as they had been in past via reverse consensus, the Trump Administration would have backed down and agreed to a deal to fill the vacant appellator seats. The US might not have given this for free; some deal might have been required to respond to the US demands regarding the jurisprudence, customary practices, and 
staffing in the Appellate Body. But if my plan had prevented the disruption of the adoptability of WTO panel reports, then the Trump Administration would have had far less negotiating leverage than it enjoys today to demand changes in the DSU to weaken the WTO compliance process.

To be sure, I have no crystal ball. My Dynamic Scenario regarding the Appellate Body may be too optimistic given the Trump Administration's concerns that the normativity of Appellate Body rulings against the US would make it marginally harder for the Administration to proceed willy nilly with more protectionist and unilateral trade measures. But if so, then the fallback of the Saved DSU Scenario would be far superior to what world trading system will suffer through now.

That's because the most fundamental advance in dispute settlement between the GATT and the WTO -- the automatic adoption of panel reports -- would have been preserved by my plan. Now, it is lost. Certainly, panel reports can still be adopted. It's just that we've lost automatic adoption of cases with violations without the approval of the scofflaw defendant.

Let me conclude with the biggest irony: I have recently been informed by a WTO insider that the Appellate Body - which is so commonly and wrongfully accused of considering itself above the rules* - was unwilling to adopt my rescue plan because they believed it was against the rules.

*See, for example, Alan Price, "Trump Administration Is Right: The WTO Is Broken," Law 360, 9 December 2019. 